\title{
The Four Critical Links of SARS-CoV-2 in Latin America and the Caribbean: Challenges for Health from the South
}

\author{
Gonzalo Basile* (10) \\ Latin American Faculty of Social Sciences Dominican Republic, International Health Program, \\ City of Buenos Aires, Argentina
}

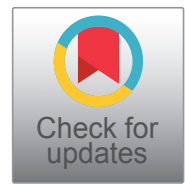

\begin{abstract}
Based on a review of the country experiences and the critical documentary analysis of contents, policies and actions, this paper characterizes the critical links in the response to the public health emergency of SARS-CoV-2 with comprehensive, reproducible claims, unique, monocultural and universal applied both to the State and to Latin American and Caribbean societies. Four links are analyzed and describe: The first, the society-nature metabolism as the determination of the pandemic process and the strengthening of a geopolitics of power in the increasing expansion of the global health security agenda as a priority of the prevailing accelerated, asymmetric and dehumanized world system; the second critical link, on the basis of an epidemiology and public health governed by microbiology in the design and management of interventions against individual and collective epidemic risk. The third critical link, articulated to this the updating of the doctrine of contagion in the $21^{\text {st }}$ century as the preeminent grammar of the sociopolitical language of human and social relations to think of an epidemic articulated to what we call the transfer of the classic clinical and institutional protocols for the prevention and control of hospital infections as massive population health measures reproduced towards society, and the fourth link, it is about the hybrids and rapid institutional arrangements for fragile, segmented and chronically underfunded Health Systems. Finally, the potentialities of a horizon of regional health sovereignty are outlined for the well-being of societies from the foundations of a new Health from the South.
\end{abstract}

\section{Keywords}

SARS CoV-2, Microbiology, Global Health Security, Health Sovereignty, International Health South-South

\section{Introduction}

In order not to repeat the philosophical-theoretical assumptions of public health as an agent of the modern state of the $20^{\text {th }}$ century, the positivist method and structural functionalism, it is essential to look at and analyze SARS-CoV-2 in a different way. "The only certainty is uncertainty" states (1999) [1]. It is in a time of uncertainty, where it seems useful to review how the global pandemic is observed and studied the epidemic risks to each country. Revitalizing Latin American critical theory in health implies, above all, in the regional context, recovering the ability to ask (oneself) and humbly assume health knowledge as a complex, contingent and multidimensional field [2]. Studying and observing the languages, actions, policies and operationalizations that were activated in the general pandemic and the epidemics, is from where to find the foundations of what is presented globally as a single positivist, universal and reproducible matrix in coping to SARS-CoV-2.

This article seeks to characterize the governance of the response to the public health emergency of SARS-CoV-2 guided by a rationality inherent to a radical biomedicalization and se- curitization that placed at the center of the global and regional strategy an epidemiology and public health/disease colonized by the protocolization of microbiology transferred to the dynamics of life in society and the reproduction of global health security parameters in the face of the accelerated destruction of capitalism.

This article identifies four critical links in the government processes with totalizing claims in the State and in Latin American and Caribbean society (Figure 1).

The link of the updating of the doctrine of contagion in

*Corresponding author: Dr. Gonzalo Basile, Latin American Faculty of Social Sciences Dominican Republic, International Health Program, City of Buenos Aires, Argentina

Accepted: May 04, 2021

Published online: May 06, 2021

Citation: Basile G (2021) The Four Critical Links of SARS-CoV-2 in Latin America and the Caribbean: Challenges for Health from the South. Ann Public Health Reports 5(1):179-192 


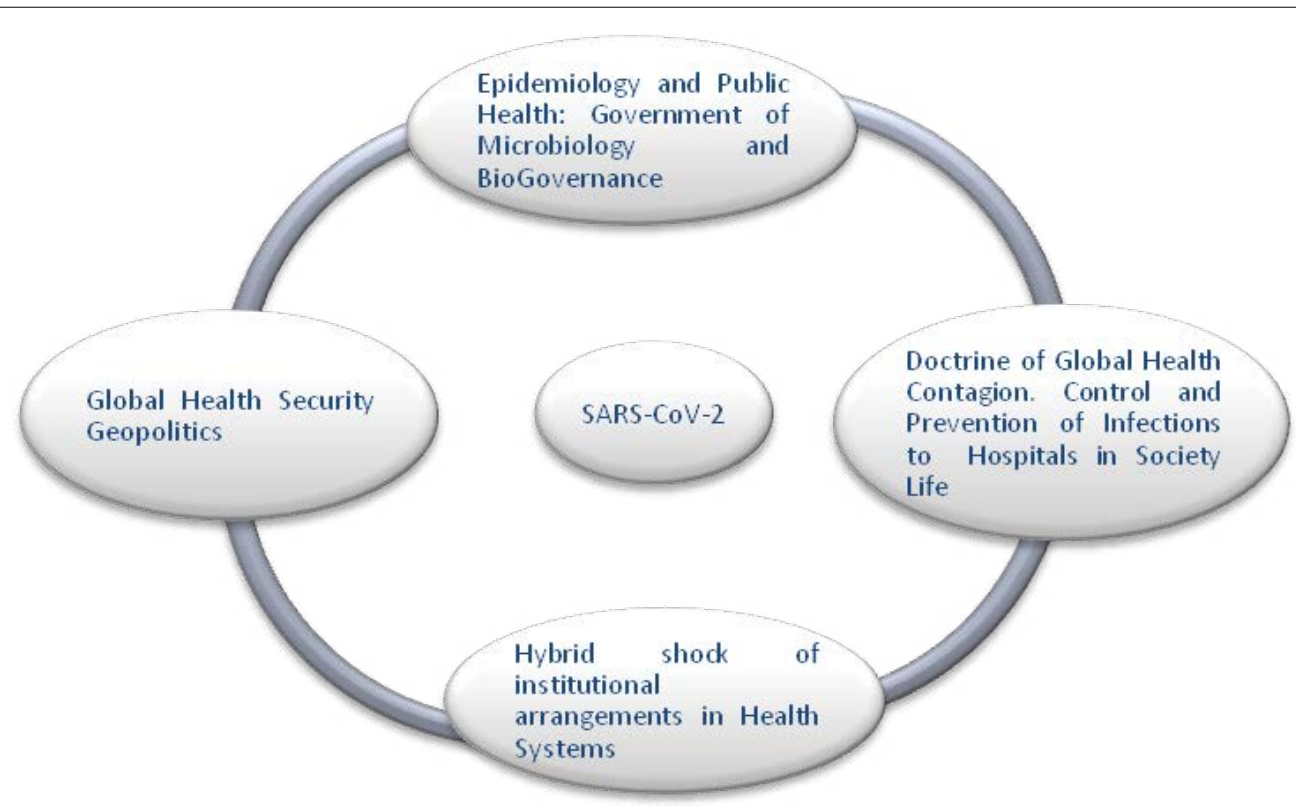

Figure 1: Article identifies four critical links in the government processes with totalizing claims in the State and in Latin American and Caribbean society.

the $21^{\text {st }}$ century as a grammar of the sociopolitical language to think about the pandemic and epidemics together with an arsenal of transfers of protocols for the infections prevention and control of hospital to life in society, is articulated with what we call the governance of microbiology in the response to the epidemic risk of SARS-CoV-2. Third, the hybrid arrangements in health systems as bureaucratic apparatuses external to society and finally, these three links responding to the geopolitics of the global health security raised as a liberal global health priority and the international medical authority of the World Health Organization (WHO) articulated to the gears of the prevailing ecocide world system [3].

On this matrix of analysis of critical links, this article develops a detailed review of these four processes that Latin American critical thinking in health has to face, to analyze, characterize and interpret the logics that are reproduced in the regional scenario of response to risk SARS-CoV-2 epidemic.

\section{International Determination of SARS-Cov-2 in Society-Nature Metabolism}

The critical process of unprecedented acceleration of economic accumulation, commodification and financialization of life, with the production of inequities by gender, social class and ethnic-racial, with dehumanizing social exclusion and ecological ecosystem destruction is perhaps the characteristic mark of $21^{\text {st }}$ century capitalism [4].

Although capitalism as the prevailing hegemonic social system colonized the human being, it produced radical changes in its mechanisms, speeds and accumulation logics between $20^{\text {th }}$ and $21^{\text {st }}$ centuries, with growing impacts on societies and, in turn, left deep traces and foundations in the Latin American and Caribbean States.

There are multiple versions and interpretations of the origin and evolution of SARS-CoV-2, although beyond the dynamics of social reproduction and virologic epidemiology, they all signify leaps in society-nature metabolism in the $21^{\text {st }}$ century.

When in December 2019 a higher frequency of new cases of coronavirus-infected pneumonia (2019-nCoV) began to be identified in Wuhan, a large city of 11 million people in central China. On December 29, 2019, the first 4 reported cases, all linked to the Huanan Wholesale Seafood Market (southern China), were identified by local hospitals using a surveillance mechanism for "pneumonia of unknown etiology" that was established as a result in the wake of the 2003 outbreak of severe acute respiratory syndrome (SARS) with the aim of allowing the timely identification of new pathogens such as 2019-nCoV [5]. The presumption of cases for zoonotic or environmental exposures was from the beginning present.

Thus, the outbreak of coronavirus (SARS-CoV-2) could arise within the commercialization of wild animals (bats, snakes, others), with most of the first cases in Chinese day laborers in precarious conditions of labor and health protection in the job.

That is, the origin of the disease, whether in this previous description, or in other versions, is a clear transfer from nature to society. It should be read in the key of metabolism between Nature and Society that allows us to recognize the interdependence of human beings with nature:

"It is a process that generates a situation of reciprocal determination between society and nature; Thus, the way in which human beings organize themselves in society determines the way in which they affect, transform and appropriate nature, which in turn conditions the way in which societies are configured". [6].

For epidemiology, the Society-Nature metabolism structures a socially determined process of the ways of living, getting sick and dying. Where anthropocentrism prevails, it 
will imply that the accelerated destruction, manipulation, commodification of society over the natural (mother earth, ecosystems), generates in an increasingly recurrent and rapid way complex processes of subsumption and subordination of nature to the needs of social accumulation that produce mutual transformations of society in the environment, and of the environment impacting society.

The connection between the natural, the biological and the social, then, is not reduced to an external link, to something "natural" or "catastrophic", since there is an internal, essential link, given by the movement described above.

The changes in the population dynamics of unhealthy and ecologically unsustainable urbanization, the loss of the natural balance of ecosystems, the introduction of exotic species, illegal trafficking or hunting, the intensive use of pesticides and contamination of land and water, massive production of waste, critical deforestation, intensive cattle raising with the use of antibiotics, food chain monopolies, in short, accumulation and dispossession territorialities, the brutal and accelerated depredation of society on nature is perhaps the greatest threat to collective health today.

SARS-CoV-2 is a health-disease process determined by this Society-Nature metabolism. For this reason, it is a key to understanding that the social determination of health and life "goes and comes dialectically between the general, particular and singular dimensions: It is reproduced from the general to the particular, and it is generated from the particular to the general. In the process, forms of subsumption occur in which the processes of the simplest dimension develop under subsumption with respect to the more complex ones and then it appears that the social-natural or social-biological relationship occurs as a movement between parts of a whole concatenated that is nature" [7].

These processes are assimilated as the sacrificial costs of development [8], or inevitable costs of progress. It is evidenced in a particularly violent way in the territorial, socio-spatial segregation with the environmental and social 'sacrifice zones' of the world-system, a term adopted by Marcelo Firpo-Porto [9]. These costs or sacrifices are intrinsically linked to a development theorization that is assimilated with analogies to the human life cycle with a linear vision of the economic evolution of societies with natural stages that the West was in charge of exporting and promoting as culture and universal roadmap to achieve one type of quality of life [10]. With an effort to generate premises in the scientific character of this theory of development, it supposed a conceptualization where all the States were dedicated to living "in development". This notion, which began to become universal in 1945, was associated with the theory of stages. It assumes that individual units, national societies, and nation-states all develop in the same way, but at different rates. Sooner or later, all states will end up being the same. Wallerstein [11] says: "This trick of illusionism implies that the more developed State could be a model for the less developed States". "Development and underdevelopment are two sides of the same coin" [12].

Now, in this context of global acceleration as the main threat to collective health and life, on the other hand, a growing medicalization of global security is consolidated as a response, considering that the circulation of these infectious diseases and new pathogens among which are account to avian flu, severe acute respiratory syndrome (SARS-CoV), Ebola, or currently SARS-CoV-2, are international threats especially for the global North [3].

This is a critical first link to review: the geopolitics of global health security [13]. An idea that forces the Southern States to take a series of health measures that respond more to the vulnerabilities of the Western States of the global North than to the real collective health needs of their societies [14]. The health-security nexus has become a dominant narrative within the health field and internationally in the last two decades [15].

This geopolitical thesis is the starting point of an interpretation that some place its origins in the year 1989, when the American virologist Stephen Morse presented the term of Emerging Infectious Disease (EID). During the 1990s, United States health and security experts interested in this concept began to measure the international threat posed by the emergence of new, hitherto unknown viruses for their national security [13]. This is how emerging and reemerging diseases flood the health literature.

At the global level, from the consolidation of liberal global health [16], the actor who came claiming to consider that this denomination of emerging diseases constituted a threat to the national security of the United States was the Center for Disease Control and Prevention (CDC) arguing that they could negatively affect both its international commercial and geopolitical interests and the public health of its citizens. The actions of the $C D C$ had a decisive influence on the success of health securitization, as demonstrated by incorporating it into the US national security agenda [17] but without considering in the least the structuring causes in metabolism. Society-nature that condition the appearance of these new diseases described above [18].

From the geopolitics of world health security, an associated global governance regime was built without considering in the least the acceleration of the colonization of nature [19] and its impacts on collective health, or the reconfiguration itself and commodification of public and common goods for life (eg, privatization of health systems, education, others).

The WHO's own international medical authority was pressured for years by the permanent demands of the US and even Canada to respond to this logic of global health security. The WHO, as has often happened in the last 30 years, assumes a clear role in responding to the geopolitical interests of the global North [20]. To adapt the international epidemiological surveillance system to these requirements, the WHO technocracies reviewed the latest regulation of the International Health Regulations that had been in force since the mid-1950s and designed a new strategy for identification, alert and response to epidemic outbreaks [21]. Thus, between 1995 and 2005, the two main strategies that make up the current global epidemiological surveillance system, the Global Outbreak Alarm Response Network (GOARN) and 
pandemic preparations, were created. Thus, with the GOARN, the WHO maintained an apparent dominance and success in showing itself as the main actor in addressing disease threats to the North and responding to these geopolitical interests. This structure is complemented by a series of NNGOs (Northern Non-Governmental Organizations) and non-state actors that respond to the global health security regime. The media also played an important role, by disseminating information regarding the threats posed by these new infectious circulations, which contributed to increase fear, anxiety and demands for protection among the US population in the logic of health securitization [22].

In this way, the current global epidemiological surveillance system is designed, which is considered a geopolitical tool in the hands of Western States that WHO experts contributed to building [13]. Which is little surprise for some that an epidemic in a pandemic phase, mainly for the global North in the United States, Canada and Europe [23], paralyzes the entire world-system and rethinks the rules of the game. Not because of the pandemic itself, but a question is being raised in that global center: what is the use of this system (read the WHO itself) that we created? The discredit of the WHO in several countries of the liberal political complex (USA, UK, Australia, among others) is growing. Of course, to a large extent the impact of Europe and the United States is what shows a special alert, financing, attention and global response of total priority for health security due to the epidemiological geopolitical impact. Once the impact on the global center has passed, the response to the pandemic and epidemic processes in the periphery will have to be monitored [18]. They would not reach the lines to have examples of other epidemics and endemics and their impact figures on millions of human lives in Africa, in Latin America and the Caribbean or on the destructive dynamics in the global South that annually accumulate preventable disease and deaths. It would give the impression that the same attention and response had never been achieved.

As Flor [13] points out, security agencies and research centers in the United States did not direct their efforts to study and transform the structuring processes of these diseases, but to build a global epidemiological surveillance system that could respond and alert to threats to "Your" security [24]. Hence the emergence of study centers from the global North that centralize working on this theoretical and methodological framework that colonizes the understanding of epidemics, pandemics, other public health emergencies: Johns Hopkins Center for Health Security, Global Health and Security Executive Program Harvard Kennedy School and Harvard Medical School, Harvard Center for Risk Analysis, Oxford Center for Tropical Medicine and Global Health, Global Health Security Index, Walter Reed Army Institute of Research, among others. A striking reference in this regard, is the Johns Hopkins Center for Health Security in association with the Davos World Economic Forum and the Bill and Melinda Gates Foundation organized "Event 201" [25], a high-level pandemic exercise level conducted on October 18, 2019 in New York City. The exercise illustrated the areas in which public/private partnerships would be necessary during the response to a severe pandemic to lessen the large-scale economic and social con- sequences says the page of "Event 201, a Global Pandemic Exercised". The disease chosen as a pandemic for modeling was a Coronavirus [25].

Global health security is a modified concept depending on the context, the pathogen and who/what is at risk [26]. The multiple grammars of security in the narrative of global health security implied forms and lenses of approaches from cases such as HIV-AIDS, SARS or pandemic flu, Ebola, Zika, among other threats. This suggests that there is a variation and readjustment reflected in the language used to distinguish the different collective health problems within the global health security narrative [27].

This trend includes year after year a growing role in military interventions, understanding health as a national security problem [15]. China's national military involvement in preparedness and response to influenza and SARS outbreaks, Peru's military-led surveillance network, Thailand's military HIV detection activities, Brazil's militarized vector control and other countries in the region for Zika and Dengue, the management of cholera by the armed forces in Zambia, Southern Command ships and incursions into Latin America for medical care of neglected diseases, and the list goes on. This is conceptually different with the parallel shift produced from world health security in the participation of the military in international quasi-invasions to respond to infectious disease concerns external to the global North as was the case with Ebola in Sierra Leone, Guinea and Libera where armies from the United States, Canada, the United Kingdom, Germany, France, among others, landed [28]. It is a modus operandi with boots on the ground to combat the threat of disease. In Africa, these military forces commanded quarantines, segregation, and confinement centers [29].

The discourse of exceptionalism (Ingram, 2013) [30], with or without generalized failures, is producing a broader systematic change for the securitization of health by normalizing the use of security forces (including military depending on the country) in emergency response public health.

The "state of war" against a disease - demonstrated in the case of Ebola and currently in SARS - CoV-2 - can seriously weaken the fundamental actions of general public health services, community-centered basic care, vaccination, of the response to endemic diseases, of women's health, of health care and protection, that is, producing arrangements in health systems with injection of anabolic response [31].

Furthermore, while diseases lacking a microbial cause are a serious burden on the health of societies in many parts of the world and also in the global South, the sudden outbreak of a potentially lethal infectious disease has a greater ability to attract attention of Western societies and the political decision-makers of the central world-system [3]. Especially in the countries of the Global North, where populations are less accustomed to infectious diseases that present a mortality risk aggravated by their demographic profile.

Finally, in the definition of danger zones and safety zones, there is a dividing line (border) that can be (un) drawn and populations on the other side. The borders between states 
were and are sites of exclusive modes of practice of security and abandonment. For governments facing risks of many kinds, there is a strong temptation to think first about the territories for which they are responsible. Migration-related and border-based biosecurity measures can therefore serve a useful internal political purpose to mitigate the anxiety of populations within a given territory. Although human mobility restrictions make it difficult to insert medical personnel or supplies between affected countries [32].

For example, the slow WHO response to Ebola in Africa in 2014 was largely driven by chronic underfunding of the WHO regional office in Africa (IDS, 2015), and the disease was also understood as a forgotten and particularly African problem and not as an international threat. This made the initial attention and the response in general partial and of low global alert. When the disease began to transform into a potential health threat to the global North, resources were clearly mobilized there [29]. With Resolution No.2177 of the United Nations Security Council in 2014 an international emergency response was imposed characterized by the creation of a global fund against the epidemic, the dispatch of Western military forces such as the United States Command for Africa and the deployment of the first international epidemiological mission [28]. These emergency actions made a decisive contribution to cutting the chain of transmission, but they also produced negative effects that we will point out below.

In addition to pointing out that the media lost interest in reporting on the disease when it ceased to pose a threat to western states [33]; subsequently, with the declaration of the end of the outbreak, the militarized humanitarian and health security intervention was concluded, thus beginning a post-emergency phase characterized by the withdrawal of international resources.

Flor [13] describes in detail how the affected African countries had to continue to face the problems caused by the epidemic such as: the destruction of their health systems, the high mortality among their health workers, the recovery of patients, the health care of others problems displaced during the epidemic and the economic recovery of its agriculture and national economy.

The securitization of the disease unfolded an emergency action that largely neglected the knowledge and capacities of African societies themselves.

The local response to the disease demonstrated the importance of care [34] and the solidarity developed by African societies to respond to the emergency and post-emergency phases of the epidemic. In this sense, various actions that point out both the importance of already established organizations and traditional authorities and therapists who contributed to informing, preventing and coordinating the response in the field [35], as well as new networks that designed programs to monitor the chain transmission and refute false information that stigmatized African culture and behavior [36]. The reinforcement of a westernized view of the African societies represented as passive and fearful was combined with the lack of interest in intervening on the international determinants of a political, ecological or economic nature of the epidemiological crisis. The African population was represented as a homogeneous, fearful and passive group at the mercy of international aid.

Faced with this process, the need to expand the frameworks of reference from south-south international health is reinforced [16] to put at the center the role that international determinations of the contemporary world system play in the geopolitical production of modes of health, living, getting sick and dying, that is, the society-nature metabolism, neoliberalism and disaster capitalism [18]. This world system has a new international health authority that emerged with liberal global health that was forgotten in the transit of the current pandemic: philanthropic foundations, the pharmaceutical industrial complex, and financial and trade organizations including the World Bank, Organization Cooperation and Development, Inter-American Development Bank, World Trade Organization that became central actors in the global health agenda [16]. The arrival of the World Bank and its neoliberal plans applied to the reforms of the health systems in several countries had direct association and coordination with the WHO itself and $\mathrm{PAHO}$, agencies that currently lead the health response. With the paradox that the same global and regional actors that promoted the fragilization of public health systems and programs are the ones that, on the other hand, appear as a "de facto" global health authority in the current context of the SARS-CoV-2 pandemic.

The global health security and national health security narrative, which had already taken hold in the global health landscape and policy-making discourse, finds in the "war" on SARS-CoV-2 a platform for global replication. This process follows the securitization logic of the Copenhagen School, according to which any problem can be perceived as a threat to security "not necessarily because there is a real existential threat but because the problem is presented as a threat." That is, the key to this understanding of the securitization of health is not the actual 'threat' of a pathogen and / or disease but an act of successful storytelling - says Wenham [27] - 'Through which an understanding is built intersubjective within a political community to treat something as an existential threat to a referent object, [generating] the support of exceptional emergency measures beyond the rules that would otherwise be required".

This will have (and has) tangible implications for global health security operations, and runs the risk of jeopardizing naturalization and future acceptance by global, regional and national societies of global health security interventions from of military and medical police interventions, and therefore associated with this also putting into (re) activation the ability to enact extraordinary measures that may always be necessary, that is, a policy of exceptionality as a new constitutive rule in the response to public health emergencies and disasters in the $21^{\text {st }}$ century.

\section{Microbiology in Public Health Governance in the Response to SARS-Cov-2}

The ideological supports, conceptions and technical-political actions and their projection on society that express the 
microbiologization of biomedical science in the government of public health currently in the framework of SARS-CoV-2 generated a complex spiral of pathologization of society, neohygienism, individual behaviorism as a theoretical-methodological body [18].

Foucault [37], in the "Birth of the Clinic", already spoke to us of a medicine that is given as a science of the individual, treatment of the sick body, basing its success in positivity through its connection with disease and death. A metaphor of the body machine with damage to its structure and function due to external or internal causes, which must be repaired. Given the success of clinical biomedicine on individual disease, it is also considered at the beginning of the 20th century that it was possible to build a public sickness [38], which will be called public health, supposedly capable of accounting for the collective disease or public, as a sum of particular diseases with vertical control actions from the States on the populations. With the positivist scientific method based on the idea of universal truth. This paradigm and machinery is what is in operation.

"Just as Medicine transforms the doctor into the magician who explains the disease and who at the same time cures it, so Public Health also transforms the State into the magician that explains the risk and prevents it. This metaphor of the magician and exorcist State on public risk and disease is fully consistent with the dominant social conception during the $19^{\text {th }}$ century and at the beginning of the $20^{\text {th }}$... The health worker of the 20th century is entrusted, then, to take care of the health of the State and of the science-technology, acting on the risk of becoming ill in the population under its charge; he must observe the population but through the glasses of state norm and instrumental reason; and it must intervene on the population transformed into an object, the same that not only must be intervened with science and technology but also has to learn to forget its particular culture that is always risky. [38].

For Edmundo Granda [38] the characteristics of conventional public health, which he will call Public Nursing, are:

- The philosophical-theoretical assumption of illness and death as a starting point for the explanation of health;

- The positivist method to explain the risk of illness in the population, and structural functionalism to understand social reality;

- The recognition of the power of the State as a magician of privileged force to ensure the prevention of disease and control of risks; with the functionalist assumptions of interpreting people as individual objects or populations as collective objects.

This conventional public health was colonized by the government of a microbiological biomedicine in command of the management, planning, preparation and population response to SARS-CoV-2 [3].

In the current global pandemic and epidemics, a grammar and language of coping was built that delimited the fields of knowledge and of dealing with SARS-CoV-2.
The categories of "place", "time" and "person" that continue to be used as the foundation stone for quantitative measures of frequency (time) and distribution, the epidemiology of the XX century on SARS-CoV-2, continues to subject the thought of the conventional public health to an empiricist framework that produces a freezing of health-disease processes as essentially individual, static, passive, care and curative phenomena that are recorded as a set of isolated and loose events: counting sick people, deaths and identification of factors risk [7].

This vision that permeates public health systems, services and programs reflects in health establishments care instruments focused on individual physical-biological deficiencies or losses, focused on the disease and on the adjustment of individual lifestyles.

This theoretical-practical framework quickly produces mechanisms of individual blame for the health-disease process and is imposed as an ideological operation of a public health action, without knowing [39].

These categories of analysis and observation and registration scales are important to understand, since they produce a reductionist interpretation of the health-disease processes of society, of groups and populations, of lifestyles and their intersections by social class, ethnicity and gender. These (im) understandings have a direct impact on health information systems in general, dumping consolidated secondary sources of records of services, establishments, and health authorities based on individual-curative care with the absence or disability in the large Latin American and Caribbean territorial extensions of systematically and vertically report information on ways of living, falling ill and dying. The critical analysis of the networks of complex determinations of the health-diseasecare processes are minimized to cases, place and time.

Another significant effect in this pandemic is the rapid increase in the use of maps. As Iñiguez Rojas [40] points out, these do not eliminate but reproduce the deficiencies of the health information of the units of analysis, of the consolidation of the biomedicalization of health cartography. Maps can also become a dangerous resource, as they attractively reduce concern about limitations in the quality of information and units of measurement, in addition to incorporating other new deficiencies derived from ignorance or incorrect use of measurement methods cartographic representation of the production of social space [12].

The complexity of epidemics, at particular times, in particular territories and populations, are studied and addressed with a unit of analysis and individual observation scales, biomedicalized, healthcare-curative. But these biases are invisible. On the contrary, in real time, conclusions of a general, totalizing nature and pure scientific empiricism about SARSCoV-2 continue to be enunciated based on these reductionist and sickness assumptions [38].

These assumptions played a crucial role when it came to updating the doctrine of contagion in the $21^{\text {st }}$ century and a political-medical system that establishes the distribution of individuals side by side, isolating them, individualizing them, 
monitoring them one by one, verifying their state of health, check if they live or die and thus keep society in a space totally divided, inspected, constantly monitored and controlled by a record as complete as possible of all the phenomena that occurred. These 14th and 15th century theses were revisited and updated at great speed [3].

The conversion of Latin American and Caribbean cities and territorialities into large lazaretos [41] refers to the idea that it is possible to create a great symbolic wall to contain and eliminate the contagion of the disease. But, paradoxically, the disease itself is circulating within the same cities and societies. In short, it is about building a closed space, subject to a specific regulation, the quarantine. It is not a simple barrier that prevents the passage of an epidemic, but the place from which one can only temporarily leave healthy, purified [42].

In general terms, on the background and review of the theoretical and methodological framework of the doctrine of contagion through quarantines, which has currently been updated and implemented in several countries as the main measure of coping with the epidemic risk of SARS-CoV-2, it could be summarized that:

- It is a political-medical system based on empiricism and militarization with quarantines as a method;

- A grammar of contagion with a narrative of blaming the other, being under suspicion. Of persecution, of monitoring and punishing, transforming society from fear and mutual mistrust. With an aporophobia towards the excluded and oppressed;

- Needs the division of society into individuals in order to isolate, inspect and control;

- Tends to an extreme biomedicalization of diseases affecting the population;

- It is a disciplinary project and a new normalization due to intrinsic characteristics;

- It homogenizes society and identifies in each context factors considered dangerous and punishable;

- The measure in general becomes a belief system (secularization). Dualistic narrative prima ("This or Death").

Social medicine and collective health [43] maintained for decades that health was a historically determined social process, a dialectical movement with levels and dimensions in general, and singular. Movement and dynamics in the processes of the general dimensions of society, in the dimensions of social groups and in the singular dimensions of individuals and their daily life. That is, although the health-disease-care process is the result of social relationships and dynamics, of how one lives and works, of the subsumption of the biological in the social, the idea of health as a "state" prevailed again individual. Breilh [7] groups them into three axes of reduction: a) reduction of health to illness and the individual, b) reducing reality in health to the single plane of empirically observable phenomena, and c) attributing the movement of that reality to one-dimensional simplicity of an order mechanically determined by biological laws and/or risk factors.

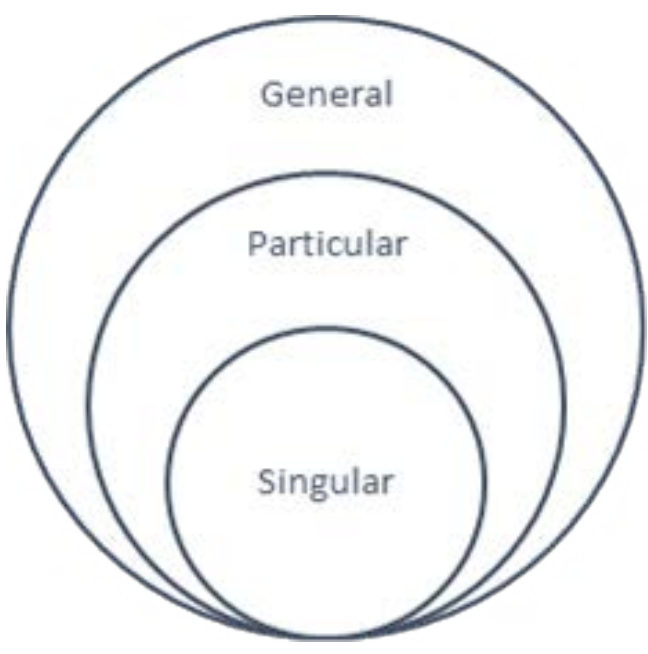

Figure 2: Levels of Analysis and Explanation of the Health Disease Process.

The general: Society-Nature. Appropriation of production and social organization; The particular: The ways of life. Social class, ethnic-gender Dynamics of Dispossession and Accumulation; The singular: The individual. Lifestyles.

So, to mitigate and control the epidemic, life in society had to be paralyzed. As if that were possible (Figure 2).

The bases of microbiological science, in the study of microorganisms from bacteria, viruses, fungi, parasites, will have key implications for what we now recognize as biomedical hegemony in the field of human health [44]. From the Dutch Antonie van Leeuwenhoek through Louis Pasteur [45] and Robert Koch, the foundations of what we know as microbiology will be configured [46]. A science applied centrally in the laboratory, the microscope and the idea of the discovery of the infectious agent (bacteria in the beginning) as specific causal agents in the production of diseases. From where the famous causal triad of infectious agent-host-environment develops. Of course, microbiological science will expand its capabilities in immunology and virology as biomedical scientific branches [47].

Now, when stating microbiology, we are referring to stating a set of devices and explanatory narratives of the mechanisms of pathogenicity of the different groups of microorganisms, of transmission and associated clinical pictures, of the main diagnostic tests of infectious diseases, the basic principles of immunotherapy and associated problems or antimicrobial therapy and the problem of resistance to treatments [48]. That is, a recipe book framed within the infectious biomedicine that from the singularity of the pathogenic process will be producing mechanisms, norms and behaviors to be followed not only for the individual at their singular risk, but supposedly extrapolated to attend to the health of society [3].

This infectious biomedicine is the one that entered the operating room in the preparation and response to the SARSCoV-2 epidemics. What in this article we will call the government of microbiology?

According to Matus [49], the government is a triangle that moves between the project, governance and the ability 
to govern. In this work we will call Government to the theoretical and methodological techno-political capacity with which social actors develop the analysis and approach of quasi-structured and complex situations and problems that occur in Society. The government not as simple "functions" or organization charts, but as a dynamic, constant and permanent process of analysis and response to complex situations and problems [50].

The microbiologization of the government is defined as the process of design and implementation of a bureaucratic apparatus of socio-sanitary interventions from the State to the society where it is possible to impose a set of meanings, simplifications, and we would say governance as unique, positivist, totalizing and reproducible.

Foucault [51] in this sense created the term governmentality, as the control of the State not only with legal issues, but also with attention to the new object to observe: The population, biologically treated, with its birth and mortality rates. A kind of capillarization of the State through health that empirically exceeds the intervention in diseases to transform itself into a mentality of control in and with society.

Currently, it could be called a process of guberbiologization where a divorce or division of labor is proposed in the government of epidemics: What professional politics does in terms of its electoral-political project is to appear in front of society to communicate the mechanisms and measures of biomedicalized government of the epidemic and of politics, and on the other the government of the design and real decision-making in the hands of the microbiologization of public health.

Of course, this process occurs in a context of extremely weak and fragile public health institutional tissues, with an accumulated structural loss of prestige to everything that is made visible as public and collective capacity, which allows the rapid reproduction of this microbiologization of the response to SARS -CoV-2 outside "the" State and Society. That is, the response capacities are in the private microbiological expertise, in the government of the individual's science experts [3].

This is generating a framework of response to epidemics with conjugations similar to evidence-based policies and evidence-based medicine [52]: The problem is who is producing "the evidence" demonstrating what should be done, of the effectiveness in population control, of the scope of quarantines, of the medical police, of a biomedicalized health-care empiricism of trial and error [3]. All the experimental trials commended by the science of the clinical individual are reported as a positive science based on an epidemiology "à la carte": The quantification of rates on disease and deaths is presented as knowledge that is not such. First "I quantify, and then I reflect. It may be necessary to first reflect, and then see what to measure and how to do it". Expanding frameworks of understanding on the units of analysis and scales of epidemiological observation and registration is to assume diverse, complex and contingent truths.

Through health language we not only describe and trans- mit knowledge, but also define action, doing, practices in the field of health, which can transform subjectivities, social conditions of life and the world in which we live, or reproduce mechanically instrumental responses of technical-normative intervention [38].

A quick country-by-country review exercise systematizing the profile of the technical-political conformation of the public health emergency operational committees, expert committees, and crisis committees, yields overwhelming evidence in this regard. Following up on the health language condensed in the institutional communication of the experts week by week from the beginning of March to the present day only allows us to verify the hegemony of an individual infectological clinical epistemology used, the attempts to provide the empirical scientificity of quarantines and the medical police policy, manages to make effective in health care institutions and in the State government itself the execution of a single truth from the scientific-technological ideology in order to prevent the risks of illness and control of society [18].

The (bio) medical knowledge as a hegemonic epistemological model [44] quickly exceeded the explanation and study of the world of SARS-CoV-2 disease and was offered as pertinent to produce knowledge about the health and quality of life of society.

It is in this context of epidemic risk where the residual scaffolding of public health as well as the State is put at the service of the government of microbiology as an expression of a radical biomedicine ready for massive experimental trials with the whole of society. But without signing an informed consent.

That is, the State was reduced as a bureaucratic apparatus external to society in the dynamics of coping with SARS-CoV-2 through the activation of experimental quarantine, hygienic and medical police trials [53]. The empirical and legal rationality that operates in quarantines and sanitation separates the State from the entire citizenry. Monitor and punish to care.

A little-addressed aspect is to describe how the (bio) clinical medical knowledge of microbiologization in the government of SARS-CoV-2 basically as a central measure transferred the practices and knowledge of infection control and prevention in health establishments [54], as practices and knowledge of infection control and prevention in the life of society. This basically led to the transfer from the protocolization languages in control and prevention of hospital infections [55], to a permanent and continuous protocolization on society:

1. Biosecurity and extreme sanitation no longer in personal and family hand washing, but in the disinfection of surfaces, clothing, footwear, metals, etc. This transferred permanent and repetitive sanitation mechanisms in daily life, as well as the surfaces and spaces of hospital care, or the sterilization of materials for sanitary use [54].

2. Intensive use of chemicals (chlorines, detergents, other disinfecting agents). Even the advertising of the 
cleaning supplies industry was intensified, commercializing all kinds of products for application to the environment and the ecosystem in search of sanitation and care.

3. The forms of entry and exit in the homes or spaces of life, where triages were implemented in formats of mobility and safe human circulation, through temperature measurements, controls of symptoms and signs, others. All empirically designed measures of a biopolitics of everyday life. Some without any foundation, others contradictory to each other depending on the place, the space, the activity, the dynamics.

4. Use of personal protective equipment with areas of use and disposal in the home, even promoting an irrational use of necessary medical protection materials, starting for example in the proliferation of the use of respiratory masks for high-risk care ended up being used in outdoor activities, in shops or recreation or for those who can afford it.

5. Aversion and phobia to the microbiome, to a supposed radical elimination of the coexistence of the human being with the viruses, parasites, fungi or bacteria that are in nature. Although at the same time the use of toxics, chemicals for agriculture, mining, and other extractive activities of nature are intensifying.

Finally, this microbiologization of public health in the face of epidemic dynamics, I implant a preparation of health establishments (especially Hospitals that are those that attend and repair the social damage of the disease), with 'parachute' activities.

Parachute actions are those where financial, human and medical-sanitary resources are pumped to a place of outbreak or public health emergency to put out a particular epidemiological fire, which can mitigate the distribution and trend of a disease at that time, but does little to systematically address the structuring processes and determinations of collective health [7] that make some populations, families, and individuals particularly susceptible to patterns of unjust and preventable diseases and deaths.

These premises, knowledge, practices, and epistemology applied to public health emergencies and social and environmental disasters in the $21^{\text {st }}$ century, as had already occurred with other endemics and epidemics, produced some institutional reflections that are registered comparatively in several countries of the region:

1. The virtual or total paralysis of the capacities of the public health systems and services (including the private sector), of the first level care networks, of the actions, programs and strategies that were carried out in basic care, chronic diseases, maternal health, childhood health, others. All possibly insufficient and fragmented, but necessary.

2. A delay of 100 days for the territorialization of the active response to the public health emergency, with activation of an epidemiology of proximity, intelligent and of health networks working in each micro-area, neighborhood, territory, community and territoriality. Search, investigation and monitoring. On day 100, the same governments and ministries and PAHO-WHO itself that spoke only of "hospitals-beds-mechanical ventilation", began to install the premise of active case investigation, access to diagnostic tests, trackers, isolation at the community level.

3. The "black" box as it is called in epidemiology to a process that does not really know what happens in its transit. That describes the first 90 days of the SARSCoV-2 epidemic in most Latin American and Caribbean countries: no reagents for diagnostic tests, centralized laboratories, low response capacities in research and family epidemiological monitoring, makes that first trimester where a social paralysis was implanted, is a hole of in-depth knowledge about what was really happening with the dynamics of the epidemic health-disease process in society.

4. Closed health information systems continued to repeat an epidemiology with 20th century numbers, making biased inferences to daily repetition in the monitoring of frequency rates, distribution through provisional records, and a constant (mis) information as the only truth daily epidemic process

This entire matrix of microbiologization operationalization could not be expanded without the aid of the Pan-American doctrine platform [56] of the Pan American Health Organization (PAHO-WHO), which once again operated on Latin America and the Caribbean as a territory of its domain and expansion of its health interests. Pan-American international health and the liberal global health of the WHO international medical authority in general organically respond to geopolitics of power and knowledge of the global North and its world system [16].

From a decolonial point of view, it is important to describe Pan-Americanism as the current that hegemonizes international public health in Latin American and Caribbean territory since the end of the 19th century and throughout the $20^{\text {th }}$ [57]. In other words, the strategies, policies, programs and interventions those was carried out and are being carried out in the region of "the Americas" as a uniform whole and repeatedly cannot be understood without this Pan-American matrix in between.

It is not by chance that daily we find reports of SARS-CoV-2 for the Americas where the United States and Canada are epidemiologically accounted for as part of a "single" region. Nor is it a surprise that Pan-Americanism reproduces health intervention matrices based on massive population control as a premise, persecution and medical police, militarization of public health emergencies, an obsolete twentieth-century sickness and epidemiology that promotes phase trials, experts, predictions, experimental measurements [57].

\section{The Critical Link of Health Systems}

Finally, the accelerated institutional arrangements in the logic of rapid preparation (beds, mechanical ventilation, health personnel, others), were related to a response of 
health systems that were chronically underfunded, fragile, privatized, stratified, segmented, financialized and especially with a growing loss of capacities to care for and protect the health of societies [58].

The State was reduced to the preparation of a bureaucratic apparatus external to society in the dynamics of coping with SARS-CoV-2 that took shape and institutionalization through quarantines, (neo) individual hygienism and medical police in the $21^{\text {st }}$ century with a certain focused assistance. The past, condensed in the institutions, weighs on the present. The State is an institutional condensation of social and power relations within a society. It is evident that the Latin American and Caribbean States carried the weight of their past and the trajectories of reforms to the health systems.

The conjugation of public health emergency operational committees filled with mostly male clinical experts, state bureaucracies with security forces and / or the military in the center of public institutions, and, on the other hand, postulates of hyper-sanitized lifestyles, changes in individual behaviors, which are repeatedly narrated, tried to be implemented in neoliberalized health systems and exclusive, inequitable and unequal societies in the region.

In this epidemic regional context it was completely invisible as the policies, theorizations based on foundations of the global North led to the installation of Eurocentric social protection models in their residual liberal pattern, of Bismarckian meritocracy or the universalism that did not allow to solve the social question of inequality in health care and social security in Latin America and the Caribbean. All Eurocentric theoretical models repeated to this day. In addition, this is conjugated with the waves of shock of neoliberal reforms to the State and the health systems commanded by the World Bank, the Pan American Health Organization (PAHO) and the Inter-American Development Bank, which in 30 years reconfigured the assets public and collective groups and further weakened the weak situation of the health systems [58]. Selective amnesia of the societies and governments of the day that, in response to an epidemic cycle with significant population attack rates, could not explain why underfunded health systems and services chronic deficits in their health facilities in response capacity had, care critical intensive and protection.

Apparently the Health Systems and the State in Latin America and the Caribbean accumulate these institutional and organizational changes promoted by international organizations, economic-financial actors and the liberal political complex, repositioning health systems in the regional and global neoliberal political agenda, but what type of institutionality and organization are they proposing to us?

As the liberal Kutzin pointed out, universal health coverage (UHC) is "a set of objectives pursued by the health system", and it is "a direction rather than a destination" [59]. This directionality implies transforming the CUS into the platform of the liberal political complex to relaunch the reforms of (un) regulated markets in health systems and build a new liquid discursive grammar with an umbrella narrative where everything fits under this denomination even the expansion of financial insurers and the private sector. What this approach centrally raises is a dynamic where the reform of the health system itself should allow the structuring of plural markets with regulated competition in coverage and access to health care. Translation: build differential health coverage through different insurances by social stratum, with differential service packages, and by separating the functions between the State and the market, opening the door to intermediation and financial modulation of insurers, the market of competing providers and associations. public-private. Chile, Colombia, Peru, Dominican Republic: emblems. In Latin America there is a phrase that summarizes this: "The sure thing about a health insurance system is that it is unsafe" [58].

Confronted with this critical link, the need to decolonize (us) from these theories and policies on Latin American and Caribbean health systems in the 21st century continues to be an outstanding debt and a great regional crossroads [58].

The great capacity for innovation and transformation in a redesign of the relations between Society and State is where the starting point is located to rethink this critical link of Health Systems in the $21^{\text {st }}$ century. The transformation of the administrative apparatus of the State to make it more democratic, intercultural, efficient, effective and oriented to society is a universal demand. Now the response to this demand is conditioned both by the theoretical approach that guides this change, as well as by the options for political action adopted and by the technical capacity of governments to implement the strategies enunciated and / or elaborated. Also, in the technical-political capacity of social movements and civil society that promote final results but have severe difficulties to get out of an enunciative solutionitis and manage to tackle really complex problems [50].

The first change to address this critical link is to leave behind the concept of reform as a concept to think about and create new health systems in the $21^{\text {st }}$ century.

It is time to eliminate the word reform. It is a functionalized, worn out, obsolete concept, but especially instrumentalised by the health agenda of the liberal and developmentalist political complex in Latin America and the Caribbean [58]. No "reform reform", no "modernization", no "present state", no "smart state", no "welfare state". Re-foundation.

To know from the South, to refound from the South. Knowing the specificities and geopolitical implications of power and a new knowledge about Health Systems from our South demarcates the need for an epistemic horizon and for innovative political action. The enunciations cannot continue to rotate in the thesis of a retrotopia of nostalgia back to an idealized $20^{\text {th }}$ century developmental public health or to the reform cycles of the regressive reforms of the $21^{\text {st }}$ century.

Refoundation sets up a new starting point. If the transformation processes of the public sphere, including Health Systems, are transitional processes. Begin to build new processes implies the potentiality and possibility of unfinished, complex processes, in permanent transition, movement and change. Assuming the transitional character of the policies, strategies and changes for a re-foundation implies a whole challenge in the canonical question of getting away from the ideologies 
that transformation only begins when one "arrives" or when one "enunciates" it, from certain saving personifications or it is simply that one person or leader, the Party or a technocracy will do it better than another. Build a transitional directionality [60].

Boaventura de Sousa Santos [60] assumes that the re-founding of the modern patriarchal colonial capitalist State implies pushing the limits of the public political imagination.

Addressing this critical link implies a task of resignifying the theories and policies on Health Systems for Latin America and the Caribbean. Refoundation does not mean the elimination of existing health systems. It presupposes recognizing capacities for reengineering and institutional-organizational architecture that underpin the re-founding of the public sphere and in this case the (re) construction of health systems for the challenges of the $21^{\text {st }}$ century.

Of course, it is not so easy to analyze and stimulate new and creative reflections, because the great risk is always to subject them to old analytical and conceptual matrices, incapable of capturing innovation and novelty in an emancipatory key, or because tendencies quickly appear to devalue, ignore or demonize these exercises. It is evident that for a long time there will be a distance between the formulations, approximations, statements of re-foundation and the practices of transformation of the materiality of health systems.

Now, the conceptualization of the re-foundation of Health Systems starts from discomfort, nonconformity, self-criticism and review of the preceding processes in the field of critical theory in health [58]. It is not about going back to a functionalist public health of the $20^{\text {th }}$ century. Although it also (re) imagining means facing various resistances to the new. Conceived not only as a conceptual or theoretical threat but also as a political and cultural threat to certain actors, organizations, technocracies and economic-political interests that colonized the reforms. Also, to (inter) generational resistance. The re-founding of health systems in Latin America and the Caribbean assumes the need for regional health autonomy and sovereignty in the face of health coloniality tests of the Pan American Health Organization (PAHO).

The theorizing on universal health systems means a critical review of Latin American social medicine / collective health itself in the construction of a new knowledge that will treat the social determination of health and life as the foundation of the bases of universalism of public goods and common to live well in the South. The organization of universal systems as a strategy for coping with determination [61]. This is part of the review and understanding that it is not a simple medical perspective of universalizing biomedicine and vertical public health of population control, of "eradicating", "eliminating", "monitoring", "fighting" diseases in populations and people. A new universality that is not also presumed as totalizing truth and logic, but intercultural and democratic. The diversity.

The explanatory theoretical framework of the Latin American critical health theory [57] assumed that a model of health organization, networks and management that was built from the universality/diversality, integrality and interdependence of public and common goods is from where health and life are more effectively de-commodified, and the needs of the complex and inequitable societies that Latin America and the Caribbean still maintain are more efficiently responded to. The premise that continues to this day is that a comprehensive and universal system as a public and common good is the safest thing for the collective health of society.

\section{By Way of Final Reflections: Decolonize and Rethink Health in the South}

The design of the governance process for the management and response to the SARS-CoV-2 emergency should continue to be studied for a long time, all the approaches are provisional, especially due to the intrinsic characteristics that this article describes regarding the critical links. Concatenated and articulated microbiologization and individualization of risk, the pre-eminence of a State nursing public health, the transfer of responsibilities and biomedical protocols to the life of the Society, together with a hybridization of health systems, and a growing militarization and punitiveness in the field of collective health.

The normalization of a type of global governance process of the pandemic that we call the "governance of microbiology" expanded in the national territories of the epidemics and the geopolitics of securitization at a global level are key elements to understand the new nexus between security and health, in a goverbiologization of the public sphere and the current world system [62]. Assuming an indisputable question: Too many collective health problems (in addition to SARS-CoV-2) are now framed in links of a narrative of global health security and national security, crossed with a growing biomedicalization and doctrine of contagion both in relationships. Human, social and international relations.

It is important to continue investigating the implications of this expansive movement in Latin America and the Caribbean and to ask if they are only concepts born to limit the cross-border spread of epidemic infectious diseases and what risks are posed by normalizing these security, goverbiologization and population control interventions in the field of collective health

The characterization of the response formulations to the SARS-CoV-2 health emergency with such ambiguous, empirical, experimental, individualizing, sanitizing, biomedicalized, microbiologized, totalizing, exceptionally securitized and dually explained and developed contents from a growing blame on societies; they are transforming the exceptional and fear into the norm and new grammars and social health interventions are being generated that could be adapted to multiple new contexts, populations, moments and particularities in the future horizon.

The first challenge posed by the development of this work is to assume the decolonization of knowledge in the study, geopolitical action and public policies of health internationally, including a critical epidemiology of the international determinations of health and life, that is, of epidemiological crises and public health emergencies [7]. 
Assuming the bases of Latin American critical thinking with the proposal of the epistemologies of the South [63], it is to start from a positioning from the geopolitical South. Boaventura de Sousa Santos defines it as "the search for knowledge and criteria for the validity of knowledge that give visibility and credibility to the cognitive practices of classes, peoples and social groups that have been historically victimized", he would say "since the oppressed "of the South. In practice, it means building a new epistemology of International Health from the South. A new epistemology of the world represented in a view of health from the South [16].

Analyzing the constitutive and reproductive processes of knowledge of liberal global health in the current pandemic, an evident impulse of decolonial turn appears as a necessity [64]. The Puerto Rican Maldonado-Torres helps define and measure this process and its implications in this way:

"...The concept of decolonial turn and its plural, decolonial turns, refer to a change in the coordinates of thought from which modernity is conceived as intimately, if not constitutively, linked to the production of multiple colonial relationships, and decolonization as a project or possible horizon of change. The foundation of decolonizing thought and the decolonial turn itself lies in the emergence of a new type of subject..."

The concepts of decolonial turn and decolonial turns [65] reveal an international character and the meaning of forms of thought that are simultaneously inspired by the crisis of thought and the project of civilization of the global Center (Eurocentrism) for a On the other hand, and in the affirmation of possibilities of being, of power, and of knowing that go beyond the constitutive limits of Eurocentric modernity, on the other. They are complemented by what Aníbal Quijano, et al. [66] conceptualizes of the coloniality of power and knowledge, considering it necessary to analyze the direct and indirect implications in the process of rethinking and resignifying international health in a South-South key.

Precisely the birth and process assumed by the regional working group on international health and sanitary sovereignty of Latin American Council of Social Sciences (CLACSO, for its acronym in english) seeks to recreate a public space for the construction of geopolitical health thought and action to problematize, develop a conceptual understanding and explanation- methodological that allows helping to dismantle which are the fallacies of the hegemonic proposals of global health and which could be counter-hegemonic proposals for our societies of the South, in this case focused on the ideology of a new International Health from a South-South, decolonial, intercultural geopolitical and health sovereignty.

It is in this sense, redefining and resignifying a new International Health of South-South coordinates, it is substantial to see how the social and health-disease processes resulting from the critical intersections between living conditions and international health determinations are analyzed [7] with the gears of modernity, capitalism, patriarchy and coloniality and its consequences in terms of the inequalities and inequities prevailing in the societies of the periphery.

It is about building an epistemological proposal of con- ceptual frameworks, studies and research, methodological practices and public policies as well as political action on the framework of a new South South International Health. Hence, point out 5 structuring principles in this first approach to South South International Health [16]:

1. Health Sovereignty: Complementing the dependency theory to the challenges of the $21^{\text {st }}$ century and Helio Jaguaribe's theory of autonomy [67], it is defined as: Seeking the maximum capacity for interdependent decision in the prevailing global context and counteracting the hegemonic logics of the system world is perhaps a substantial premise that allows a genuine capacity to formulate policies, goals and emancipatory strategies based on the actors, societies and decisions of the South themselves. We call this regional Health Sovereignty.

2. Decoloniality/Decolonial turn: As Maldonado Torres,et al. [65], Arturo Escobar and Chantra Mohanty detail, the dynamization of a change in the coordinates of emancipatory thought from which the liberal modernity of the global Center is conceived and its structuring and reproductions are subverted in the ways of thinking and doing in health.

3. Interculturality: If the epidemiological situations of our peoples are particular, if the health-disease process is a historically constructed and determined object in each society, if the very concept of disease is dependent on the sociocultural construction, why are our models, services and systems health are in many actions almost copied and standardized? Interculturality assumed not only as an instrumental measure of communication or language or asymmetric multiculturalism of beliefs, but from a political dimension where Interculturality implies de-westernization, ecology of knowledge and distribution of power.

4. South South: It implies thinking and acting as an epistemological subject of the geopolitical South. Geopolitical orientation, cartography and counter-hegemonic praxis. It implies a new epistemology of Health from the South [63].

5. Horizontality: It has communicating vessels with intercultural dialogue and the ecology of knowledge. It is not just non-asymmetrical relationships between people, groups and / or collective representations. Especially it is the principle that establishes the limitation of hierarchical, conditioning, asymmetric relationships, understanding that the perspectives assumed in the SISS should be based on the recognition of the Other, reciprocity, cooperation between equals and solidarity association.

The only way to end a government architecture [68] for the response to the SARS-CoV-2 public health emergency is by building a more relational, polyphonic, intercultural and complex one [2]. Refound an innovative amalgam of epistemological plots between the Latin American critical thought expressed in the new current of Health from the South [16] 
and the long tradition of social medicine and collective health of the $20^{\text {th }}$ century [69]; as a contribution to a practice that aims to awaken critical health science from paralysis in the pandemic and post-pandemic period.

Getting out of fear and exceptionality is an obligation of Latin American critical thinking in health. The region has a long history and learning tissues from where to think about its own re-foundation for a new Health from the South.

\section{References}

1. Morin E (1999) The seven knowledge necessary for the education of the future. UNESCO, Paris P. 5-12.

2. Almeida-Filho $\mathrm{N}$ (2006) Complexity and transdisciplinarity in the field of collective health: evaluation of concepts and applications. Journal Collective Health/Revista Salud Colectiva 2: 123146.

3. Basile $\mathrm{G}$ (2020) Coronavirus in Latin America and the Caribbean: Between the shock therapy of public sickness and the response of collective health / international health South South.

4. Breilh J, Tillería Muñoz Y (2009) A global acceleration and dispossession in Ecuador: The decline in the right to health in the neoliberal era. Quito, EC: Simón Bolívar Andean University/Universidad Andina Simón Bolívar, Campus Ecuador.

5. Qun Li M, Xuhua Guan, Peng Wu, at al. (2020) Dynamics of early transmission in Wuhan, China, of novel coronavirus-infected pneumonia. The New England Journal of Medicine, 382: 11991207.

6. Toledo V y Gonzáles M (2005) Social metabolism: The relationships between society and nature, in Francisco Garrido, et. al., edit, The ecological paradigm in the Social Sciences, cap. 3, Press, Barcelona, P: 4.

7. Breilh J (2013) The social determination of health as a tool for transformation towards a new public health (collective health). Journal of the National School of Public Health/RevistaFacultad Nacional de SaludPública 31: 13-27.

8. Machado-Aráoz H (2012) The pains of Our America and the neocolonial condition. Extractivism and biopolitics of expropriation. Social Observatory of LatinAmerica/Observatorio Social de América Latina, Buenos Aires, 32.

9. Firpo-Porto M (2013) Environmental injustice and health in Brazil: mapofconflicts. Rio de Janeiro: Fiocruz, P: 133-174.

10. Rist G (2002) The development: History of a western belief. Book Catarata/Los libros de la Catarata, Madrid, P: 8-28.

11. Wallerstein I (2006) After developmentalism and globalization, what?. Polis. Revista Latinoamericana, P: 13.

12. Santos M (2000) The nature of space: Technique and time, reason and emotion. Barcelona: Ariel.

13. Flor JL de la (2018) Global health security under debate. Critical Lessons Learned from the 24th EVE. Comillas Journalof International Relations 13: 49-62.

14. Rushton S (2011) Global health security: Security for whom? Security of what?, Political Studies 59: 779-96.

15. McInnes C y Lee K (2006) Health, security and foreign policy, Review of International Studies 32: 5-23.

16. Basile G (2018) South South International Health: Towards a decolonial and epistemological turn. In II Dossier de Salud Interna- cional Sur Sur, EditionsGT Salud Internacional CLACSO, Argentina.

17. King NB (2002) Security, disease, commerce: Ideologies of postcolonial global health. Social Studies of Science, 32: 763-789.

18. Basile G (2020) The triad of quarantines, neohygienism and securitization in SARS-CoV-2: Genetic matrix of the doctrine of Pan Americanism in health. Editions GT Salud Internacional y Soberanía Sanitaria CLACSO, Argentina.

19. Escobar A (2011) Political ecology of globality and difference. Thecolonizednature. In Politicalecology and mining in Latin America/Ecología política y minería en América Latina, 61-92.

20. Davies SE (2008) Securitizing infectious disease. International Affairs, 84: 295-313.

21. Fidler D (2005) From international sanitary conventions to global health security: The new international health regulations. Chinese Journal of International Law4: 325-392.

22. Wald P (2007) Contagious: Cultures, carriers, and the outbreak narrative. Duke University Press.

23. Our World in Data (2020) Confirmed cases and confirmed deaths by Covid-19. Oxford University.

24. Aldis W (2008) Health security as a public health concept: A critical analysis. Health Policy and Planning, 23: 369-375.

25. CJHHS (Center Johns Hopkins for Health Security). (2019). Event 201.

26. Flor JL de la (2015) The global health security device. In O Mateos y J Tomas (Coord.), Behind Ebola. A multidisciplinary approach to a global issue. Barcelona: Editions Bellaterra.

27. Wenham C (2019) The over-securing of global health: Changing the terms of the debate. International Affairs 95: 1093-1110.

28. Burci GL (2014) Ebola, the security council and the securitization of public health. Questions of International Law 10: 27-39.

29. Honigsbaum M (2017) Between securitisation and neglect: Managing Ebola at the borders of global health. Medical history 61: 270-294.

30. Ingram A (2013) After the exception: HIV/AIDS beyond salvation and scarcity. Antipo-de, 45: 436-454.

31. Heymann D, Lincoln Chen, Keizo Takemi, et al. (2015) Global health security: The broader lessons from the Ebola virus disease epidemic in West Africa. The Lancet 385: 1884-901.

32. McInnes C, Lee K, Youde J, y Enemark C (2020) Biosecurity and global health risk. In The Oxford Handbook of Global Health Politics: Press University Oxford.

33. Sendín JC, y Nieto MR (2015) Media in the international treatment of the Ebola crisis. In O Mateos y J Tomas (Coord.), Behind Ebola. A multidisciplinary approach to a global issue. Barcelona: Editions Bellaterra.

34. Álvarez A (2015) When caring can mean contagion. The gender dimension in the Ebola. In O. Mateos y J. Tomas (Coord.), Behind Ebola. A multidisciplinary approach to a global issue. Barcelona: Editions Bellaterra.

35. Tomas J (2015) Traditional authorities, cultural dynamism and Ebola. A reflection. In O Mateos y J Tomas (Coord.), Behind Ebola. A multidisciplinary approach to a global issue. Barcelona: Edicions Bellaterra.

36. Bajo Erro C (2015) ICT and commitment to face the threat. The 
Citation: Basile G (2021) The Four Critical Links of SARS-CoV-2 in Latin America and the Caribbean: Challenges for Health from the South. Ann Public Health Reports 5(1):179-192

epidemic in the hyperconnected society. In O.Mateos y J Tomas (Coord.), Behind Ebola. A multidisciplinary approach to a global issue. Barcelona: Editions Bellaterra.

37. Foucault M (1999) Birth of biopolitics. In: Essential Works/Obrasesenciales. Barcelona: Paidós, 3: 209-215.

38. Granda E (2004) What we call collective health, today. Cuban Journal of Public Health/Revista Cubana de Salud Pública 30 $1-20$.

39. Zizek S (2003) How did Marx invent the symptom?" In Ideology. A map of the question. Buenos Aires. Fund of Economic Culture/ Fondo de Cultura Económica.

40. Iñiguez Rojas L (1998) Geography and health: Themes and perspectives in Latin America. Notebooks of Public Health/Cadernos de SaúdePública 14: 701-711.

41. Fernández Carril (1865) Importance of lazarettes and quarantines. In Actas de las sesiones del Congreso Médico Español. Celebrado en Madrid, P: 225.

42. Bonastra Q (2010) Sanitary enclosures and control spaces: A morphological study of quarantine architecture. Dynamis, 30: 17-40.

43. Paim JS, Almeida Filho NMD (1999) The public health crisis and the collective health movement in Latin America. Repository UFBA, 75: 5-30.

44. Menéndez EL (2005) The medical model and the health of workers. Journal Collective health/Saludcolectiva, 1, 9-32.

45. Debré P (1995) Louis Pasteur. Book Club/Círculo de Lectores, Barcelona.

46. Collard P (1976) The development of Microbiology. Cambridge University Press, Cambridge, UK.

47. Engleberg C, DiRita V, Dermody T (2007) Mechanisms of Microbial disease. $\left(4^{\text {th }}\right.$ edn). Lippincott Williams \& Williams.

48. Prats G (2006) Clinical Microbiology. Editorial: Medica Panamericana.

49. Matus C (2007) School of government. Journal Collective health/ Saludcolectiva 3: 203-212.

50. Matus C (1987) Politics, planning and government. Caracas: Fundación Altadir.

51. Foucault M (2008) Security, territory, population: Course taught in the Collège de France (1977-1978). São Paulo: Martins Fontes.

52. Fernández Sacasas JA (2011) Controversies around evidence-based medicine. Journal Habanera of Medical Sciences/ Revista Habanera de Ciencias Médicas 10: 339-347.

53. Mantovani R (2018) what was the medical police? In History, Sciences, Saúde-Manguinhos/História, Ciências, Saúde-Manguinhos, 25: 409-427.
54. PAHO (2011) Rapid evaluation guide for hospital programs for the prevention and control of health care-associated infections. Washington DC, USA.

55. OMS (2018) Infection Prevention and Control (IPC) Assessment Framework (IPCAF). WHO/HIS/SDS/2018.9 (c) World Health Organization.

56. Rapoport M (2008) UNASUR, the opposite of Pan-Americanism. In América Latina en Movimiento. Quito, junio.

57. Basile, G. (2019) The health of the regional integration process: The case of UNASUR SALUD. Sovereignty or health dependency? CLACSO.

58. Basile G (2020) Rethinking and decolonizing the theory and policies on Health Systems in Latin America and the Caribbean. CLACSO.

59. Kutzin J (2013) Health financing for universal coverage and health system performance: Concepts and implications for policy. Bull World Health Organ 91: 602-611.

60. De Sousa Santos B (2010) Refoundation of the state in Latin America. International Institute of Law and Society, Lima.

61. Breilh J (2010) Epidemiology: Political economy and health. Structural bases of the social determinationofhealth. ( $7^{\text {th }}$ edn) Universidad Andina Simón Bolívar / Corporación Editora Nacional, Quito.

62. Dussel E (2004) World system and transmodernity. In Colonial modernities/Modernidades coloniales, 201-226.

63. De Sousa Santos, B y Meneses MP (2014) Southern epistemologies. Akal.

64. Escobar A (2007) The decolonial turn: Reflections for an epistemic diversity beyond global capitalism. Century of Man/ Editorial Siglo del Hombre.

65. Maldonado-Torres N (2008) Decolonization and the decolonial turn. Tabula rasa 9: 61-72.

66. Quijano A (1999) Coloniality of power, culture and knowledge in Latin America. Dispositio 24: 137-148.

67. Jaguaribe $H$ (1978) The imperial condition. El Trimestre Económico 45: 21-50.

68. Nogueira MA (1998) As possibilities of politics. Ideas for the democraticre form of the State. São Paulo, In Paz e Terra.

69. Iriart C, Howard Waitzkin, Jaime Breilh, et al. (2002) Latin American social medicine: Contributions and challenges. Pan American Journal of Public Health Organization 12: 128-136.

DOI: $10.36959 / 856 / 517$

Copyright: (C) 2021 Basile G. This is an open-access article distributed under the terms of the Creative Commons Attribution License, which permits unrestricted use, distribution, and reproduction in any medium, provided the original author and source are credited. 